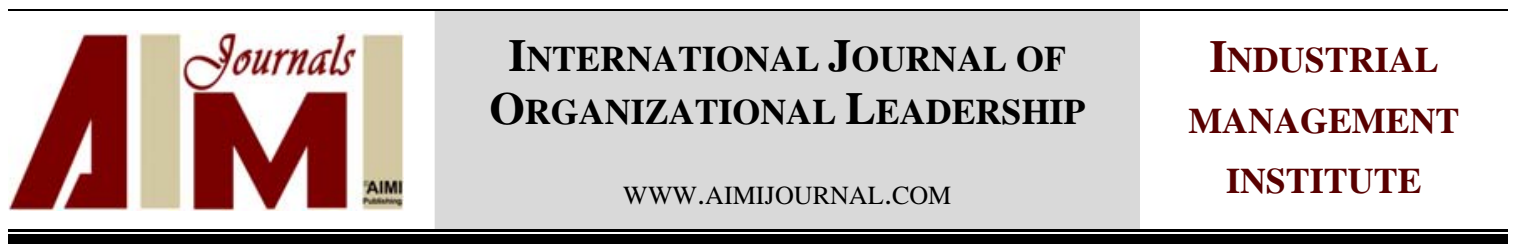

\title{
The art of packaging: An investigation into the role of color in packaging, marketing, and branding
}

\author{
Behzad Mohebbi \\ University of Mohaghegh Ardabili, Ardabil, Iran
}

\begin{abstract}
Keywords:

Packaging, Marketing,

Branding, Color,

Psychology of Colors

Correspondence:

mohebi_behzad@yahoo.com

The purpose of this study is to contribute to the existing research in the field of packaging and marketing and shed more light on the psychology of colors and their effect on packaging and marketing. Nowadays, packaging is proved to be one of the significant factors in the success of promoting product sale. However, there is a perceived gap with respect to the different aspects of packaging, in particular the graphics, design, and color of packaging. The current study provides a comprehensive overview of packaging. It elaborates on different aspects of packaging and summarizes the findings of the most recent research conducted to date probing into packaging from different perspectives. It also discusses the role of color, i.e., the psychology of colors, and graphics in packaging and product sale. It is argued that graphics and color play key roles in promoting product sale and designers and marketers should attach a great deal of importance to color in packaging. The implications for producers, marketers, practitioners, and researchers are discussed in detail and suggestions for future research are provided.
\end{abstract}

(C)AIMI Journals

\section{Introduction}

Nowadays, the strategic role of comprehensive development in flourishing of a society is highlighted. To achieve this development, managers need to take advantage of all potential tools. One of the main indicators of success in international markets is paying close attention to marketing, in particular packaging. Today, in line with the basic aim of packaging, which is keeping the product safe and making the transportation easy, packaging is considered as an 
effective advertising tool which would promote sale. The importance of this field of graphics is to the extent that in some countries which are not producer, they take advantage of effective packaging for imported goods which put their names as the producer and exporter of the product. Surprisingly enough, 70 per cent of all brand and purchase decisions are made in-store at the moment of buying, even if a consumer enters a store with the intention of purchasing specific products based on a shopping list (Kauppinen-Räisänen, 2014). So, packaging, without a shadow of doubt, exerts a significant impact on consumers' decision at the point of purchase.

There is now a growing consensus among researchers and practitioners in the field of marketing and business that packaging plays a pivotal role in the success or failure of sale of any product in the highly competitive market. It is evident that companies in order to outperform their leading competitors need to invest effort and money in product differentiation; to this end, product packaging is one of the most effective and marketoriented strategies which companies can adopt (Stoll, Baecke, \& Kenning, 2008). However, there is a gap in the literature examining packaging from different perspectives, in particular the factors such as the color of packaging which exert an impact on its effectiveness. This study presents an investigation into the status quo of packaging research through summarizing the findings of the most recent studies conducted in this field and the effect of the art of packaging and color on the success of product sale.

The remainder of this article is organized as follows. Firstly, we discuss the status quo of packaging; then, we elaborate on the findings of the most recent studies conducted to date investigating packaging. This is followed by a discussion about the role of graphics in packaging, in particular color and color psychology and its contribution to packaging. After this, the implications of this study is discussed in detail as well as conclusions and potential directions and suggestions for further research in the field of packaging and marketing.

\section{Packaging: The State-of-the-art}

By and large, packaging plays a crucial role in product success, especially in the fast moving consumer goods industry and exercises a significant effect on consumers' buying decisions (Simms \& Trott, 2010). In fact, changes in retailing and marketing have given packaging a central role in large and well-developed industry in emerging consumer society (Porter, 1999). It is observed that most of consumers make their purchase decision at the store shelf; 
this evidence highlights the immense importance of packaging in affecting consumers' pointof-purchase decisions (Underwood \& Ozanne, 1998).

In fact, until the end of the nineteenth century, in majority of sectors of economy of USA packaging was limited to simply tying up a parcel with wrapping paper and string (Porter, 1999). Packaging received paramount importance since the 1950s when self-service retailing was burgeoning (Kauppinen-Räisänen, 2014). Unfortunately, traditionally, packaging design was given a subordinate and minor role with regard to production systems design and product design (Azzi, Battini, Persona, \& Sgarbossa, 2012). In a similar vein, as Simms and Trott (2014) rightly stress, packaging has received little attention in marketing and there is a lack of robust theory in this field of study.

The functions which packaging is required to perform are fundemental, complex, and manifold (Hellström \& Saghir, 2007). Packaging is intimately related to marketing communications, logistics and distribution management, sustainable marketing, and branding (Simms \& Trott, 2010). In fact, packaging serves three main communication functions, namely communication of information including content, destination, and means of handling, promoting the product, and enahancing communication with consumers (Hellström \& Saghir, 2007).

Precisely speaking, packaging serves key roles and functions in enhancing marketing. Silayoi and Speece (2007) summed up the main packaging elements which potentially exert influence on consumers' buying decision, including visual and informational elements; the visual elements relate to graphics and color and size or shape of packaging and informational elements consist of information about the product and the technologies used in the package. More recently, Simms and Trott (2014), based on the studies conducted examining different aspects of packaging, summarized concisely the key roles and functions of packaging. Table 1 presents these key roles and functions of packaging.

Given the importance of packaging, for instance, for perishable foods, packaging informs consumers about allergy, nutritional preferences, or even discounts; also, the freshness of a perishable product can be read-out from the information provided in packaging (Heising, Dekker, Bartels, \& Van Boekel, 2014). For perishable foods, intelligent packaging can be used which "monitors conditions of food during its life cycle to communicate information related to the quality of the product" and as well as "contains sensors or indicators to estimate and communicate quality of a food product to user" (p.645). 
Table 1

The Key Roles and Functions of Packaging (Adapted from Simms \& Trott, 2014)

\begin{tabular}{|c|c|}
\hline Key roles and functions & Elements of packaging's role \\
\hline Protection & $\begin{array}{ll}- & \text { Effects on the supply chain } \\
- & \text { Tamperproof } \\
- & \text { Role in transportation and logistics } \\
- & \text { Product safety and quality }\end{array}$ \\
\hline Containment & $\begin{array}{ll}\text { - } & \text { Preservation/shelf-life of the product } \\
\text { - } & \text { Protection from hazards: mechanical, chemical; } \\
\text { environmental; climatic; bacteriological } \\
\text { - } & \text { Aids customers use of product } \\
\text { - } & \text { Containing and holding product } \\
\text { - } & \text { Quantity/amount } \\
\text { - } & \text { Facilitating/convenience handling } \\
\text { - } & \text { Affect on quality } \\
\text { - } & \text { Compatibility and constraints }\end{array}$ \\
\hline Identification & $\begin{array}{ll}\text { - } & \text { Product identification } \\
\text { - } & \text { Labeling (effective) } \\
\text { - } & \text { Information: Copy/illustrations on use }\end{array}$ \\
\hline Marketing communication & $\begin{array}{ll}\text { - } & \text { Supporting marketing communications } \\
\text { - } & \text { Supporting promotion of other products } \\
\text { - } & \text { Sales/marketing } \\
\text { - } & \text { Positioning }\end{array}$ \\
\hline Cost & $\begin{array}{ll}\text { - } & \text { Transport and storage costs } \\
\text { - } & \text { Process cost implications }\end{array}$ \\
\hline User convenience & $\begin{array}{ll}- & \text { Openability/access } \\
- & \text { Reclosability } \\
- & \text { Carrying } \\
- & \text { Dispensing facilities } \\
- & \text { Affecting consumer value } \\
- & \text { New solutions } \\
- & \text { Consumer convenience }\end{array}$ \\
\hline Market appeal & $\begin{array}{ll}\text { - } & \text { Suitable quantity/format } \\
\text { - } & \text { Consumer and market appeal } \\
\text { - } & \text { Branding } \\
\text { - } & \text { Reinforcing the product concept } \\
\text { Ability to improve sales }\end{array}$ \\
\hline Innovation & $\begin{array}{ll}\text { - } & \text { Facilitating commercialization } \\
\text { - } & \text { Innovation and technology }\end{array}$ \\
\hline
\end{tabular}

Although the effeciency and primary importance of packaging is neglected in developing countries and non-competitive markets, but the value of packaging market is a multi-billion dollar business which mainly belongs to the developed and industrialized countries. Given ecommerce and online sales servise via Internet through companies such as eBay and Amazon, salespersons and venders are to lose their important and key roles in promoting sale; this circumstances leads producers, experts, and practitioners of marketing and business to focus on the key role of packaging in fostering product sale. In modern sale systems, packaging, which is commonly employed and advocated in developed and industrialized countries, is 
one of the most important factors in promoting sale due to the fact that in these systems the closest relationship of a consumer with a product is not through salespersons but through the packaging. It is crystal clear that poor graphics and design of packagaing would have detrimental effects on consumers' attitudes and lead to poor sales performance.

As already mentioned, there is a lack of comprehensive theory in marketing, in particular packaging. To bridge this gap, Simms and Trott (2014) based on a grounded theory methodology provided a new understanding of how a new product's packaging is managed effectively and integrated into the new Product Development Process (NPD). The original version of this grounded framework of management of packaging in NPD is accessible through http://www.emeraldinsight.com/action/showImage?doi=10.1108\%2FEJM-12-20120733\&iName=master.img-001.jpg\&type=master.

It is also clear that in line with packaging, branding, also, is "among a company's most priceless assets" (Hernández, 2011, p. 369) which results in band equity which is the value a brand name adds to the product. Packaging and branding, taken together, have the potential to position producers and companies at a vantage point against their competitors in highly competitive market through enhancing the consumer likelihood to purchase a product. In actual fact, consumers' responses to the design and color of packaging is assumed to be converted into brand preference; simply put, the decision to opt for a brand is based on aesthetics of packaging (Kauppinen-Räisänen, 2014).

In the same line of argument, it is imperative to mention that packaging exerts a crucial influence on two key factors, namely brand equity and consumer loyalty which would result in prompting successful marketing (Aurier \& de Lanauze, 2012).

Silayoi and Speece (2007) argue that "the package becomes a critical factor in the consumer decision-making process because it communicates to consumers at the time they are actually deciding in the store" (p.1496). They also go as far as to claim that the way consumers perceive the subjective entity of produces they want to purchase, as represented through graphics, color, design, and communication elements in the package, exercise an impact on their choice and is regarded as a key to succeed in product marketing strategies.

In the most recent study, Ryynänen and Rusko (in press) investigated the professionals' view of consumers' packaging interactions. They concluded that "By understanding the phenomena in the everyday lives of consumers, companies can develop packaging that goes hand in hand with consumers' lives and practices. In this view, packaging is the consumers' partner in using the product, not a disconnected medium for sending messages" (p. 13). They 
also claimed that "For the consumer, well-designed packaging means functional and pleasing experiences that are seamlessly integrated into everyday life. Successful consumer-centered packaging development can benefit a company by creating a competitive advantage, increasing customer satisfaction and boosting sales volumes" (p. 13).

\section{The Role of Graphics and Color}

Color is an excellent source of information as much as it is estimated that 62-90 per cent of persons' assessments and evaluations is based on colors alone (Singh, 2006). Colors have dramatic and profound effect on consumers' thoughts, feelings, and behaviors; so, marketers have long employed color as a visual mnemonic device to support cognition and thought and grasp consumers' attention (Labrecque, Patrick, \& Milne, 2013). As Odekerken-Schröder, Ouwersloot, Lemmink, and Semeijn, (2003) rightly stress when consumers want to make a purchase, they usually take several factors and dimensions into account. There is a consensus among marketing scientists and managers that product form or design and product aesthetics are indispensable tools to gain competitive advantage in competitive market (Kreuzbauer \& Malter, 2005). As Kauppinen-Räisänen (2014) argues, "one means of capturing discerning consumers is through the strategic use of visual cues" (p. 663). She goes as far as to claim that packaging design is a strategic brand issue which should be attached primary importance in marketing.

Visual stimuli on packaging attract consumers' attention and leads consumers to form perceptions of various products; these perceptions significantly exercise influence on consumers' buying decision (Venter et al., 2011). Graphics and color are decisive factors in affecting consumers' purchase decision which producers and marketing experts should not turn a blind eye to them in packaging. Graphics includes image layout, color combinations, typography, and product photography (Silayoi \& Speece, 2007).

Accordingly, it is observed that extrinsic product cues, namely packaging color is influential in buying decision, in particular consumers who are in hurry, which is typical in today's hectic life style, rely on packaging color and design in making purchase decisions (Kauppinen-Räisänen, 2014).

As a matter of fact, researchers, designers, and producers should not ignore attentioncapturing attributes of packaging. It is evident that consumers' first impression is based on the packaging, especially the graphics and color. An eye-catching graphics and color would result in lasting effect on consumers' purchase decision. In fact, attractiveness, which can be 
obtained through graphics and color, at the point of buying plays a key role in getting brand choice (Silayoi \& Speece, 2007).

Kauppinen-Räisänen (2014) rightly asserts that the multifarious and multiple functions of packaging colors, particularly how colors attract consumers' attention and plays an influential role in affecting perceptions at the point of buying is under-researched area of investigation in the field of packaging and marketing.

Based on the studies conducted to date examining packaging color, it is concluded that consumers take advantage of colors as stimulus-based information and packaging color captures consumers' attention, affects preferential judgments, and has the ability to communicate the information about the product at the point of purchase (KauppinenRäisänen, 2014).

In her most recent research, Kauppinen-Räisänen (2014) provides a framework which indicates the functions of packaging color at the point of purchase. Figure 1 presents this framework.

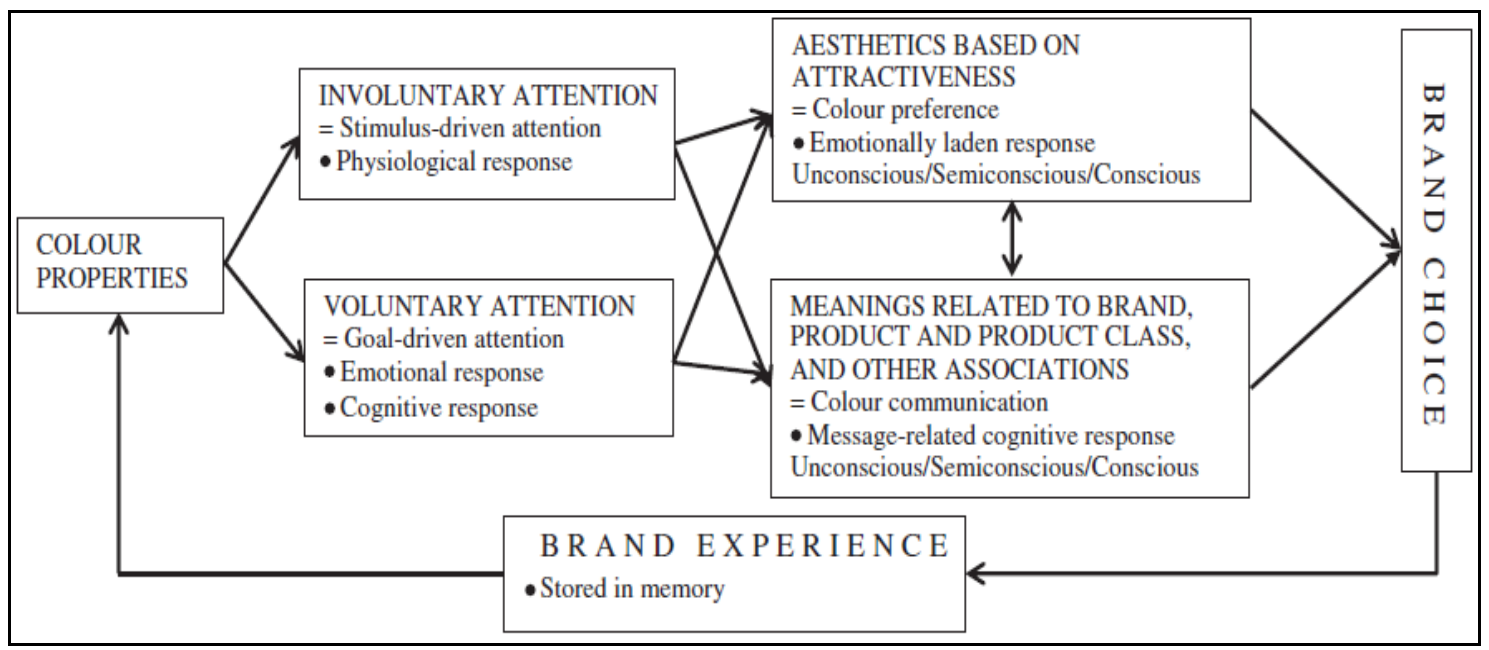

Figure 1. Packaging colors' functions at the point of purchase (Adapted from Kauppinen-Räisänen, 2014).

As Figure 1 clearly exhibits, the framework takes into consideration the three main functions of packaging color, including voluntary or involuntary attention, aesthetics, and communication. Interestingly enough, packaging colors exercise an influence on emotions and the responses and reactions to packaging color can be unconscious and innate, semiconscious based on cultural factors, or conscious under the influence of personal preferences based on personal experiences (Kauppinen-Räisänen, 2014). 
Silayoi and Speece (2007), employing a conjoint analysis approach, examined the importance of packaging attributes. Based on the data obtained and the analysis, they argued that the most effective packaging is required to have a technology image conveying clearly convenience and ease of use; provide the information of product clearly and comprehensively; and have more classic and traditional graphic design, colors, and shape.

Bix, Seo, and Sundar (2013) studied the impact of color contrast on consumers' attentive behaviors and found that simultaneous contrast of colors significantly affects the attentive behaviors of consumers, their perception of quality of the product, visual appeal, and purchase intention.

As already mentioned, visual elements, namely graphics and color, placement of visual elements, and packaging size and shape are among the determining factors enhancing product sale. Given packaging color and its undeniable role in affecting consumers' purchase decision, researchers and practitioners need to focus on psychology of colors and color preferences of consumers which are context and culture-specific. The findings of research into color preferences indicate that color preferences are intimately related to determining factors such as age and gender, personality, and ethnicity and religion (Kauppinen-Räisänen, 2014).

In other words, similarly, it is argued that " the perception and application of color is strongly influenced by ones innate physiological and psychological predisposition, personal experiences, age, gender, personality, income, ethnographic and demographic" (Singh \& Srivastava, 2011, p. 199).

In brief, it is imperative to stress that colors are of primary importance in persons' daily life and especially in marketing, branding, packaging, and product sale. Table 2 summarizes the connotations and significance of different colors in daily life and particularly in marketing based on Singh and Srivastava (2011).

By and large, packaging designers are required to take advantage of colors' connotations in designing packaging and combining different colors to attract consumers' attention in making purchase decision. For instance, Crowley (1993) claimed that designers can use more activating colors such as red and blue to engage consumers in impulse buying. So, it should be highlighted that selecting the right colors and artistic and psychological combination and design of them in packaging would prompt product sale dramatically. 
Table 2

The Connotations of Colors in Daily Life and Marketing

\begin{tabular}{|c|c|}
\hline Color & Connotation \\
\hline Red & $\begin{array}{l}\text { celebration, purity, passion, strength, energy, fire, love, excitement, speed, heat, arrogance, } \\
\text { ambition, leadership, masculinity, power, danger, blood, war, anger, revolution, and communalism }\end{array}$ \\
\hline Blue & $\begin{array}{l}\text { depression, tranquility, trust, confidence, conservatism, dependability, wisdom, wealth royalty, } \\
\text { truthfulness, and creativity }\end{array}$ \\
\hline Green & $\begin{array}{l}\text { growth, rebirth, renewal, nature, fertility, youth, good luck, generosity, health, abundance, stability, } \\
\text { and creative intelligence }\end{array}$ \\
\hline Yellow & $\begin{array}{l}\text { sunlight, joy, earth, optimism, intelligence, hope, liberalism, wealth, dishonesty, weakness, greed, } \\
\text { decay aging, feminity, gladness, sociability and friendship }\end{array}$ \\
\hline White & youth, sterility, light, reverence, truth, snow, air, cleanliness, coldness, fearfulness and humility \\
\hline Black & $\begin{array}{l}\text { absence, rebellion, modernity, power, sophistication, formality, elegance, mystery, style, evil, } \\
\text { emptiness, darkness, seriousness, conventionality, unity, sorrow, professionalism, and sleekness }\end{array}$ \\
\hline Gray & $\begin{array}{l}\text { elegance, respect, reverence, wisdom, old-age, pessimism, boredom, decay, dullness, urban sprawl, } \\
\text { intense emotions, balance, mourning, and neutrality }\end{array}$ \\
\hline Orange & $\begin{array}{l}\text { energy, heat, fire, playfulness, gaudiness, arrogance, warning, danger, desire, royalty, and religious } \\
\text { ceremonies and rituals }\end{array}$ \\
\hline Brown & $\begin{array}{l}\text { calmness, boldness, depth, natural organisms, richness, tradition, heaviness, poverty, dullness, } \\
\text { roughness, steadfastness, simplicity, dependability, friendliness and aids in stimulating appetite and } \\
\text { is popularly used for advertising various bakery products, chocolates, foods and flavors }\end{array}$ \\
\hline Pink & $\begin{array}{l}\text { gratitude, appreciation, admiration, sympathy, socialism, health, } \\
\text { feminity, love, marriage, joy, innocence, flirtatiousness, childlike behavior and symbolizes sweet } \\
\text { taste }\end{array}$ \\
\hline Purple & $\begin{array}{l}\text { nobility, humility, spirituality, ceremony, mystery, wisdom, enlightenment, flamboyance, } \\
\text { exaggeration, sensuality, pride, and lavender essence }\end{array}$ \\
\hline Indigo & spirituality and intuition \\
\hline Violet & elegance, grace and artistic creativity \\
\hline Magenta & artistic creativity \\
\hline Rose & optimism, hope and love and used in advertising to signify rosy flavors \\
\hline
\end{tabular}

\section{Concluding Remarks and Suggestions for Future Research}

The present study contributes to a growing body of research investigating the effect of packaging and the role of different mediating factors such as graphics, design, and color which contribute to the success of branding and marketing. Future researchers in this field of inquiry, as Azzi, Battini, Persona, and Sgarbossa (2012) rightly concluded, should focus on identifying methods and procedures for an integrated and systematic packaging design and take into account various variables which exert influence on packaging. Kauppinen-Räisänen (2014) highlights that marketers need to be "alert to the wide-ranging effects and functions of packaging and packaging colors" (p. 670). 
Further research is welcomed investigating the issues related to packaging color, in particular color aesthetics, color communication or meanings expressed by colors, color attention, color properties, and the inter-relationships between the different color functions and roles in different contexts and cultures. Also, as Singh (2006) mentions, future studies are advised to examine the effect of cool and warm and dim and bright colors on product sale.

In future research it will be of interest to study the impact of cultural and social differences' effect on packaging color and design, branding, marketing, and more importantly product acceptance and sale. It is evident that products do not exist in a vacuum; hence, it is argued that branding, marketing, and packaging require placing a physical entity, i.e., the product, into socio-culturally constructed world of symbols, signs, signifiers, and more importantly contexts of consumption in which the product is advertised, sold, purchased, and used (Verma, 2013).

Another potential area for future study could focus on more holistic packaging approach through considering multifunction of packaging to avoid negative trade-offs (Hellström \& Saghir, 2007). In the same vein, further studies, as Hellström \& Saghir (2007) rightly call for, are expected to adopt a systems-oriented approach towards the evaluation of packaging concepts and the factors which have an impact of packaging. Additionally, one further research goal that can be pursued in future research is to investigate consumer response to packaging through longitudinal and qualitative research.

Also, researchers can inquire into the possible roles of intelligent packaging and the barriers to implement this kind of technology in packaging (Heising, Dekker, Bartels, \& Van Boekel, 2014). Moreover, future researchers in this field of study can examine the combination of art and technology and its effectiveness on prompting marketing, packaging, and product sale. Further research into designing and implementing environmentally friendly and sustainable packaging should be conducted to offer strategies to be implemented in design of packaging to avoid packaging waste and contamination from packaging (Scott \& Vigar-Ellis, 2014).

In brief, Elliot and Maier (2007) concluded that psychology of color, the functions of color, and assessment and calibration of lightness, chroma, and hue "is a highly promising research area in which many pressing questions await empirical consideration" (p. 253).

In a nutshell, it is hoped that the present study would serve as a stimulus for future and more in-depth research into packaging and the variables involved in its success, in particular the graphics, color, and design. 


\section{References}

Aurier, P., \& de Lanauze, G. S. (2012). Impacts of perceived brand relationship orientation on attitudinal loyalty: An application to strong brands in the packaged goods sector. European Journal of Marketing, 46(11), 1602-1627.

Azzi, A., Battini, D., Persona, A., \& Sgarbossa, F. (2012). Packaging design: General framework and research agenda. Packaging Technology and Science, 25, 435-456.

Bix, L., Seo, W., \& Sundar, R. P. (2013). The effect of colour contrast on consumers' attentive behaviours and perception of fresh produce. Packaging Technology and Science, 26, 96-104.

Crowley, A. E. (1993). The two-dimensional impact of color on shopping. Marketing Letters, 4(1), 59-69.

Elliot, A. J. , \& Maier, M. A. (2007). Color and Psychological functioning. . Current Directions in Psychological Science, 16 (5), 250-254.

Heising, J. K., Dekker, M., Bartels, P. V., \& Van Boekel, M. A. J. S. (2014). Monitoring the quality of perishable foods: Opportunities for intelligent packaging. Critical Reviews in Food Science and Nutrition, 54(5), 645-654.

Hellström, D., \& Saghir, M. (2007). Packaging and logistics interactions in retail supply chain. Packaging Technology and Science, 20, 197-216.

Hernández, L. P. (2011). Cognitive tools for successful branding. Applied Linguistics, 32(4), 369-388.

Kauppinen-Räisänen, H. (2014). Strategic use of colour in brand packaging. Packaging Technology and Science, 27, 663676.

Kreuzbauer, R., \& Malter, A. J. (2005). Embodied cognition and new product design: Changing product form to influence brand categorization. The Journal of Product Innovation Management, 22, 165-176.

Labrecque, L., Patrick, V. M., \& Milne, G. R. (2013). The marketers' prismatic palette: A review of color research and future directions. Psychology \& Marketing, 30(2), 187-202.

Odekerken-Schröder, G., Ouwersloot, H., Lemmink, J., \& Semeijn, J. (2003). Consumers' trade-off between relationship, service package and price. European Journal of Marketing, 37(1), 219-242.

Porter, G. (1999). Cultural forces and commercial constraints: Designing packaging in the twentieth-century United States. Journal of Design History, 12(1), 25-43.

Ryynänen, T., \& Rusko, E. (in press). Professionals' view of consumers' packaging interactions- A narrative analysis. Packaging Technology and Science. Retrieved from http://onlinelibrary.wiley.com/journal/10.1002/\%28ISSN\%2910991522/earlyview

Scott, L., \& Vigar-Ellis, D. (2014). Consumer understanding, perceptions and behaviours with regard to environmentally friendly packaging in a developing nation. International Journal of Consumer Studies, 38, 642-649.

Silayoi, P., \& Speece, M. (2007). The importance of packaging attributes: A conjoint analysis approach. European Journal of Marketing, 41(11), 1495-1517.

Simms, C., \& Trott, P. (2010). Packaging development: A conceptual framework for identifying new product opportunities. Marketing Theory, 10(4), 397-415.

Simms, C., \& Trott, P. (2014). Conceptualizing the management of packaging within new product development: A grounded investigation in the UK fast moving consumer goods industry. European Journal of Marketing, 48(11), 2009-2032.

Singh, N., \& Srivastava, S. K. (2011). Impact of colors on the psychology of marketing-A comprehensive overview. Management and Labour Studies, 36(2), 199-209.

Singh, S. (2006). Current research development: Impact of color on marketing. Management Decision, 44(6), 783-789.

Stoll, M., Baecke, S., \& Kenning, P. (2008). What they see is what they get? An fMRI-study on neural correlates of attractive packaging. Journal of Consumer Behaviour, 7, 342-359.

Underwood, R. L., \& Ozanne, J. L. (1998). Is your package an effective communicator? A normative framework for increasing the communicative competence of packaging. Journal of Marketing Communications, 4(4), 207-220.

Venter, K., van der Merwe, D., de Beer, H., Elizabeth, K., \& Bosman, M. (2011). Consumers' perceptions of food packaging: An exploratory investigation in Potchefstroom, South Africa. International Journal of Consumer Studies, 35, 273-281.

Verma, H. V. (2013). Coffee and tea: Socio-cultural meaning, context and branding. Asia-Pacific Journal of Management Research and Innovation, 9(2), 157-170. 